\title{
Pension Funds: Administrative and Investment Cost
}

\author{
Jan Pokorný ${ }^{1 *}$, and Pavlína Hejduková ${ }^{1}$ \\ ${ }^{1}$ University of West Bohemia, Faculty of Economics, Department of Finance and Accounting, \\ Univerzitní 8, 30100 Pilsen, Czech Republic
}

\begin{abstract}
The pension funds show us the alternative to the unfunded systems. This is the reason for long-terming attention. Disadvantages of funds financing include problems as indexation, inflation, or administrative and investment costs, which are decreasing the future profit for pensionary and efficiency of pension funds. This study aims to describe and analyse the administrative and investment costs and the determinants that affect these costs. The method of literary research and search of professional studies focused on empirical analysis of administrative and investment costs is used. Furthermore, the method of analysis and synthesis is used. The result of this study is an indication of the content and significance of costs and the definition of the main determinants influencing these costs. A prerequisite for the quality functioning of pension funds is the organization of the labor market and a high share of active participants. Determinants that increase costs include the number of participants in pension funds and total assets, the guarantee of income by the pension fund, and some investment instruments. Based on a search of empirical studies, the existence of economies of scale was confirmed. The limit of the study is the comparison of several countries where different legislation operates.
\end{abstract}

\section{Introduction}

In 1981 the pension reformation was conducted in Chile, which became an inspiration for the rest of the countries while making the pension systems. The reformation consisted of the transition from public unfunded system (known as PAYG) to fully funded. It means a mandatory savings program, where the residents have individual pension accounts. Other countries were inspired by this reformation of pension systems and decided on the privatization of part of the pension systems or implementation of these pension schemes [1].

Considering that, the pension systems became the main interest of politics in many countries because the ability to reformation the pension systems is a very important question due to social, financial, and fiscal sustainability.

The transition to fully funded schemes is of further importance because of the aging population. Limited population growth, together with an aging population, causes public finance revenues allocated to pension systems to fall, while pension expenditures increase.

\footnotetext{
${ }^{*}$ Corresponding author: pokorny@kfu.zcu.cz
} 
As a result, deficits are created in the imaginary public pension accounts of individual states. The way to fix this is, according to some countries, is the involvement of the private sector.

The reform of Chile has become an example of how the change can be taken a place. However, Chile was able to take advantage of its undemocratic establishment at the time of the introduction of the funded pension scheme. In the case of countries with democratic governance, it is necessary to perceive the possible problems with acceptance of the reform regarding the individual interests of agents, who may influence, for example, the rules for private entities that set up individual pension accounts.

In the 1990s, the privatization of the pension system was an idea that was reflected in the recommendations of the World Bank and was also used in some post-communist countries, such as Poland and Hungary. However, the result of this attempt did not turn out satisfactorily, also due to political changes [2]. Nor does the current Chilean pension system escape criticism, which was also evident in 2016, as there were nationwide protests [3].

Fund schemes, therefore, have their advantages and disadvantages for the pension system. The ideal pension system is a combination of pension schemes so that creates a robust system that will balance individual risks, which is not entirely simple, also due to the need for political permeability of this kind of solution. Withal that, an appropriate combination can address the current problems associated with public spending and its growth in pension areas [4].

Both systems, the PAYG and the fund systems have their costs, which are closely linked to the need to ensure the functioning of the institutions that take care of the operation. We call these costs administrative costs. There are other costs in fund schemes, which are called investment costs. These costs are related to what distinguishes between a public pay-as-you-go system and a privately funded system. Notwithstanding this, even the public sector can manage public fund schemes.

Administrative and investment costs are the subject of this study. The following chapter presents the scientific goal of the study and the chosen methods that serve to fulfil the goal. The third chapter focuses on administrative and investment costs and gives reasons why it is necessary to address this issue. The fourth chapter presents an analysis of scientific studies and compares the results of this work. The last chapter of this study is the Conclusion, which summarizes the results of the research.

\section{Research aim and methodology}

As it was mentioned in the previous chapter, the objects of this study are administrative and investment costs. This study aims to define the importance of administrative and investment costs and assessment of determinants of administrative and investment costs. This view is very crucial because the pension funds introduce the alternative to a public unfunded scheme.

This study serves as a literature search for current knowledge of administrative and investment costs. The authors deal with this issue mainly on the examples of Australia, the USA, the Netherlands, and Chile. The reason for choosing these countries is their focus on pension fund schemes [5].

The study analyzes the determinants that affect administrative and investment costs. For practical application we have chosen countries, which are called developing countries. In these countries the labor market is still not organised rightly [6]. The second group of selected countries is developed countries, where the labour market is organised and have quality assumption for pension funds. Developed countries in this study have long-term experience with pension funds $[5,7,8,9]$. This literature search is still relevant as it defines 
variables that can affect costs. At the same time, determinants can be influenced by a country's legal framework.

This study is about to be the literal research, which is focused on the issue of costs in pension costs. Further is used the method of description for specification of the theoretical background. The analysis is used in the parts Results and Discussion, where are introduced the costs due to different studies.

Between the resources for making this study were chosen the research papers, which were dealing with models of administrative and investment costs and they offer the solution of relationship between variabilities and the impact on the costs at all. In the same part is also used the method of deduction. In Conclusion of this work is practiced the method of synthesis for summarizing the results of this study.

\section{Administrative and investment cost}

The existence of public and private institutions, which established the pension schemes or pension funds, is connected to the existence of incomes and making of costs. The incomes are primarily represented by contributions from members or residents, so the people, who compulsorily or voluntarily participate in the given pension scheme.

On the other hand, there are costs. The initial costs that need to be mentioned are again related to the members of the pension schemes or funds. These are benefits that they usually receive based on previous participation and/or after meeting the conditions. Another important item is administrative and investment costs.

Administrative expenses represent items such as salaries of employees who take care of the operation of the institution and administrative activities associated with the existence of the pension system or fund, costs of management and marketing of the company, rent, depreciation, and other items. Thus, these are items that are necessary to ensure the functioning of the institution. Investment costs are associated with fund financing. These include items such as investment research, management, and consulting fees [9, 10].

As early as 1998, James [11] pointed out that the administrative costs of financial distortions and distributional effects posed new problems that future research should focus on. And as will be shown in the next chapter, this research focused mainly on Australia, the USA, the Netherlands, and Chile [10].

Another who dealt with the problem of pension funds and costs was Stiglitz [12]. Stiglitz [12] has generally defined several disadvantages of pension funds. These problems include indexation, the risk of inflation, difficulty to predict life expectancy (therefore it is necessary to use general prognoses that do not respect the health status of the individual). Another disadvantage, according to Stiglitz [12], is the higher administrative costs of pension funds compared to a public social security scheme.

This disadvantage is associated with what is called system decentralization. The existence of smaller pension funds creates a competitive environment. Such an environment can be advantageous in the market, but it brings marketing costs. Marketing costs aim to increase interest in a given pension fund, which should lead to an increase in the size of the pension fund. However, it would be necessary to gain ample dominance to realize cost savings from scale [13]. As James [11] points out, marketing costs can lead to the consumer choosing a pension fund that is not one of the best options.

The main reason to deal with administrative and investment costs, resp. in general, costs, are important within fund schemes. Costs represent a reduction in potential profits for clients and managing institutions. Reducing administrative and investment costs will increase the funds that can be invested. The funds invested will thus increase and may bring greater benefits, specifically mention the increase in return for a member, replacement ratio, and performance of pension fund [6]. 
Fig. 1 shows the issue of allocation of financial means on costs. Bikker [10] pays attention to the relationship between annual costs and erosion of retirement income. The model on Fig. 1 presumes annual wage growth $3 \%$, annual inflation $2 \%$, nominal return 7 $\%$. The time of contribution is 40 years and pensioner gains benefit for 20 years.

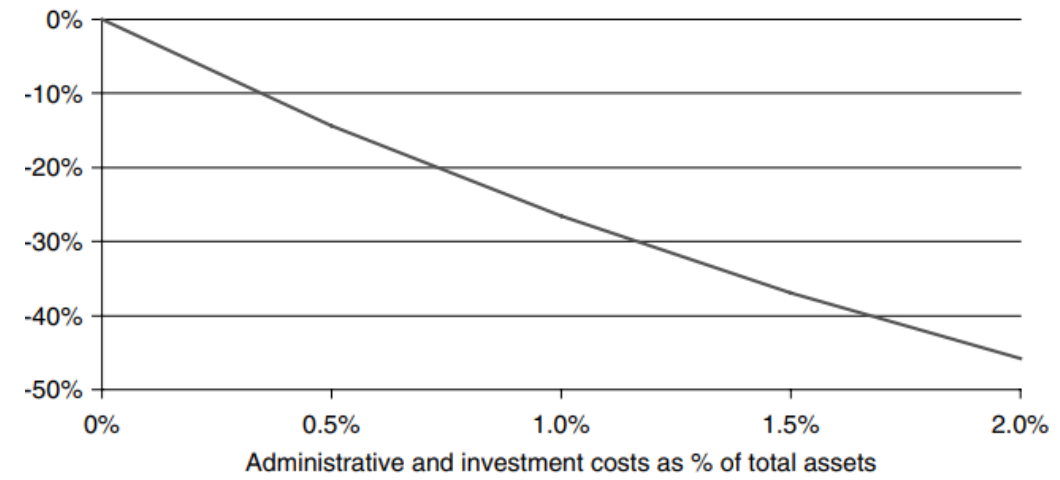

Fig. 1. Erosion of retirement benefit based on costs [10]

Another common question, that is inflected in this area, is the optimal size of pension funds. That is, whether pension funds achieve economies of scale based on the size of the pension fund and whether a U-shaped curve is generated [9]. The next chapter will be devoted to this question.

\section{Results and Discussion}

Recently, several studies have been conducted to empirically understand administrative and investment costs in different parts of the world. There are different times in different countries when pension funds were created and assets were acquired into these funds. We can take the period of existence as one of the important factors, which is essential in the existence of pension funds and the evaluation of administrative and investment costs.

Another factor is the development of the labor market itself, as evidenced by studies from Southeast Asia. While Singapore and Malaysia have more developed markets, the situation is the opposite for Thailand and Vietnam. For a larger and better-formed labor market, the organization of funded pension schemes is also better and the involvement of active participants is higher. This is also evidenced by the data in Table 1, which shows the cost concerning gross income, contribution, and assets.

Thailand and the Philippines are countries where the availability of fund schemes is shorter. At the same time, the system in the Philippines is based on a combination of investing and paying benefits to retirees in part of benefits and income. Thus, the current good demographic structure of the population is being used [6].

As mentioned, in the Philippines, part of the contributions to the current payment to pensioners is allocated, which negatively affects the performance of the pension fund and the future return of the members of the pension fund. A comparison of operating expenses and assets shows that the funds in Singapore and Malaysia have the best ratio, which is also evident in other categories. The Philippines, on the other hand, is the worst in all categories. Thailand moves between these countries [6].

Table 1. Estimated administrative and compliance costs of select pension and provident fund [6]

\begin{tabular}{|c|c|c|c|c|}
\hline Variable & $\begin{array}{c}\text { Employees } \\
\text { Provident Fund } \\
\text { (Malaysia) }\end{array}$ & $\begin{array}{c}\text { Social Security } \\
\text { System } \\
\text { (Philippines) }\end{array}$ & $\begin{array}{c}\text { Central } \\
\text { Provident Fund } \\
\text { (Singapore) }\end{array}$ & $\begin{array}{c}\text { Social Security } \\
\text { Organization } \\
\text { (Thailand) }\end{array}$ \\
\hline
\end{tabular}




\begin{tabular}{|c|c|c|c|c|}
\hline $\begin{array}{c}\text { Operating expenses } \\
\text { as share of gross } \\
\text { income }\end{array}$ & 1.77 & 6.03 & 2.48 & 3.65 \\
\hline $\begin{array}{c}\text { Operating expenses } \\
\text { as share of } \\
\text { contributions }\end{array}$ & 2.92 & 8.20 & 0.77 & 4.77 \\
\hline $\begin{array}{c}\text { Operating expenses } \\
\text { as share of assets }\end{array}$ & 0.25 & 2.13 & 0.09 & 0.63 \\
\hline
\end{tabular}

Asher \& Bali [6] see the reason for a large number of inactive members in the Philippines (about one-third). Another reason is the low level of compliance, ie the already mentioned poor organization of the labor market and law enforcement, which leads to the collection of lower contributions than they should be.

The above-mentioned problems are mainly related to developing countries and the least developed countries, which are still shaping the labor market. Other countries that will be described here belong to the developed countries [14], and therefore their labor market can be considered as creation, including the payment of basic components of wages. An overview of countries and determinants that affect administrative and investment costs is provided in Table 2.

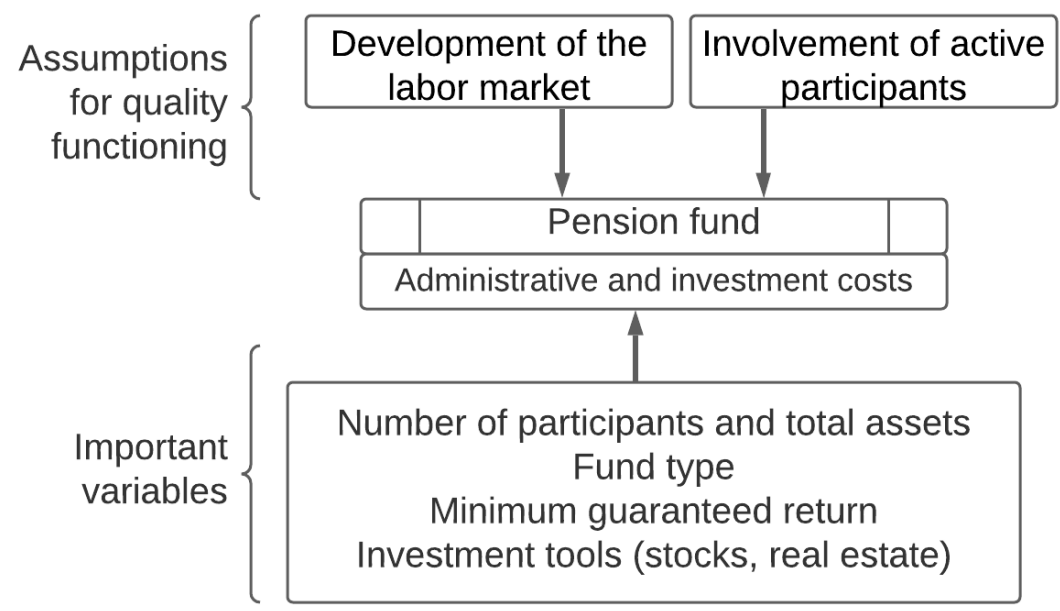

Fig. 2. Assumptions for pension fund and important variables affected administrative and investment costs

Assumptions for quality functioning of pension fund we can see on Fig. 2, where are displayed important variables. These variables have an impact on the level of administrative and investment costs.

The first of the studies focus on Italian pension funds. In this study, the relationship between cost and fund type is found. If the fund is closed for a sector or region, then its operation is more efficient than for open ones (universal funds). On the contrary, with a minimum yield guarantee, costs increase, albeit insignificant. A similar result is for share equities in total financial assets. Guaranteed schemes' net asset value has a positive effect on costs, however, this determinant in the natural logarithm harms costs. As a result, the relationship between dimension and cost is a U-shaped curve and it is possible to find savings from the range [7].

Campani \& Riddier [8] focus on the Netherlands, as does Bikker [5]. In the first study on the Netherlands, Campani \& Riddier [8] conclude that the number of participants that affects administrative costs is primary. However, costs per participant show economies of 
scale with increasing membership to a certain point, from which costs per participant increase again.

Another study [5] uses three different cost functions, here for simplification the results will be mentioned, which confirm all three functions. Furthermore, administrative and investment costs are divided here.

Table 2. Important variable of administrative and investment

\begin{tabular}{|c|c|c|}
\hline Authors & Country & Important variable \\
\hline $\begin{array}{l}\text { De Vincentiis, Isaia } \\
\quad \& \text { Zocchi [7] }\end{array}$ & Italy & $\begin{array}{c}\text { Fund type (open/close) - } \\
\text { Minimum guaranteed return }+ \\
\text { Guaranteed schemes' net asset value - } \\
\text { Squared natural logarithm of the } \\
\text { guaranteed schemes' net asset value }+ \\
\text { Share of the total financial assets } \\
\text { invested in equities }+\end{array}$ \\
\hline Campani \& Riddier [8] & the Netherlands & $\begin{array}{c}\text { Number of participants }+ \\
\text { Ex-contributors (ratio) }+ \\
\text { Real coverage ratio }+ \\
\text { Logarithm of the assets per participants } \\
+\end{array}$ \\
\hline Bikker [5] & the Netherlands & $\begin{array}{c}\text { Administrative costs: } \\
\text { Participants }+ \\
\text { Type of funds }+ \\
\text { Pensioners }+ \\
\text { Inactive participants - } \\
\text { Assets per 1,000 participants }+ \\
\text { Report invest cost - } \\
\text { Outsourcing }+ \\
\text { Investment costs: } \\
\text { Total assets }+ \\
\text { Type of funds }+ \\
\text { Stocks }+ \\
\text { Real estate }+ \\
\end{array}$ \\
\hline $\begin{array}{l}\text { Bikker, Steenbeek } \\
\& \text { Torracchi [9] }\end{array}$ & $\begin{array}{l}\text { Australia, Canada, } \\
\text { the Netherlands, the US }\end{array}$ & $\begin{array}{c}\text { Number of participants }+ \\
\text { Standardized CEM service quality score } \\
\text { and complexity score }+ \\
\text { Share of deferred participants - } \\
\text { Public sector (state or provincial } \\
\text { government and municipality) }+ \\
\end{array}$ \\
\hline
\end{tabular}

Administrative costs will be mentioned first. It is essential to confirm the achievement of administrative cost savings per participant. Other important elements include the type of fund (company, industry, professional group, or other funds). And industrial funds offer the least expensive type. Bikker [5] assumes that the reason is the universality of this fund compared to others, which offer pension plans more appropriate to the individual, but this increases administrative expenses more.

The investment cost model shows that there will be an increase in investment costs for total assets, which is around 1 according to the model chosen. Other factors that lead to growth are again the type of fund and sub-types of assets (stocks and real estate), which are more expensive, for example, against bonds, which, however, are not significant.

The last of the presented studies [9] deals with a comparison of four countries (Australia, Canada, the Netherlands, and the US) and their costs in selected pension funds. In this study, cost savings are found concerning the relationship between costs and activities performed. Table 2 shows the determinants that primarily affect growth. The 
increase in costs is associated with determinants such as the number of members and what needs to be highlighted is the focus of the pension fund (similar to the fund type from [5], here it is already focused on specific sectors). Funds for public sector employees show higher costs than funds for private-sector employees. State and provincial government funds show $70 \%$ higher administrative costs than average. There is therefore room for consolidating these pension schemes so that they are more effective [9].

The presented studies indicate which variables need to be taken into the account when examining administrative and investment costs. Based on these studies, it has been confirmed that there are economies of scale in pension funds, due to the growing number of participants and the cost per capital. However, the point that again increases costs per capita is different for each pension fund and country.

Other important variables include the type of fund that can be examined as open or closed. If the pension fund is closed, then it is possible to further examine for which group the pension fund is intended.

Guaranteeing the yield cannot be neglected either, which may be important for some states given their history and the need for security for citizens or political decisions. The Italian example shows that a guaranteed return increases costs, but the increase is not high. Of course, it depends on the specific situation of the pension fund and its performance. It is also worth mentioning the individual investment instruments, but here it is necessary to register the restrictions that can be imposed on pension funds and the allocation of assets to individual investment instruments, as stated, for example, by Kritzer [15].

\section{Conclusion}

Administrative and investment costs are part of the money market funds spent. The issue of these costs is very important, as pension funds are a possible way to implement the reforms of many countries' pension systems. At the same time, the implementation of fund schemes is also recommended by international organizations.

Administrative and investment costs, together with inflation, indexation, and life expectancy, thus form one of the key issues in the creation of pension funds. As well as the issue of financial distortions, and distributional effects. In addition, the issue of costs is linked to the performance of the funds and the subsequent payment of benefits to pensioners. By reducing costs, a higher return can be achieved for members of pension funds, and thus a consequent increase in benefits, which should be the goal of members. For pension funds, cost reductions lead to better fund management and performance.

As part of the examination of empirical studies, the preconditions for the good functioning of pension funds were defined. These assumptions include a well-functioning and organized labor market and a high proportion of active participants.

An examination of several countries has confirmed the existence of economies of scale in pension funds. This confirmation is important due to the creation of pension funds and their optimal size. The main determinants that affect administrative costs include the number of participants and the fund type, i.e. whether the fund is universal (open) or selective (closed - for a defined geographical area or sector of the economy).

Some pension funds guarantee a return, which again affects the growth of administrative costs. This link is important concerning the political permeability of the implementation of pension funds into the pension systems of states.

Investment costs are affected by total assets, i.e. it is a similar determinant as the number of participants in administrative costs. Investment tools that increase costs include stocks and real estate. However, stocks are important investment vehicles and therefore cannot be rejected as part of investment instruments. In general, for investment instruments, 
it is important to compare their return, which subsequently affects the return of the entire fund as well as the benefit paid to fund participants.

A limitation of research in the area of administrative and investment costs is the differing legislation in individual states, which may limit the number of costs or may affect the allocation of assets and the distribution of risk. At the same time, there may be other limitations that relate to the length of development of individual pension schemes. This limitation means that international comparisons may not be meaningful to some extent.

This research focused on the theoretical background and empirical research to date. Further research can thus focus on empirical evidence based on the findings of this study. As a next possibility we can mention deeper analysis of investment cost and tools due to their performance.

This paper was created within the project SGS-2020-026 'Economic and financial transformation in the context of digital society' at the University of West Bohemia, Faculty of Economics. 


\section{References}

1. K. McKiernan. Social Security reform in the presence of informality. Review of Economic Dynamics 40, 228-251 (2021).

2. J. Vostatek. Penzijní teorie a politika. (Praha: C. H. Beck, 2016)

3. M. J. Azocar. Policy Debates on Pension Reform in Chile: Economists, Masculinity and the Mobilization of Strategic Ignorance. SOCIAL POLITICS 27, 648-669 (2020).

4. B. Heer, V. Polito, M. R. Wickens. Population aging, social security and fiscal limits. Journal of Economic Dynamics \& Control 116, 103913 (2020).

5. J. A. Bikker. Is There an Optimal Pension Fund Size? A Scale-Economy Analysis of Administrative Costs. Journal of Risk and Insurance 84, 739-769 (2017).

6. M. Asher, A. S. Bali. Public Pension Programs in Southeast Asia: An Assessment. Asian Economic Policy Review 10, 225-245 (2015).

7. P. DeVincentiis, E. Isaia, P. Zocchi. Institutional disparities and asset allocation homologation in Italian defined contribution pension funds. How do they affect the guarantee commitment? Journal of Pension Economics and Finance 16, 205-232 (2017).

8. C. H. Campani, I. De Ridder. Administrative costs of Dutch pension funds: the impact of fund characteristics. Economics Bulletin 39, 1361-1370 (2019).

9. J. A. Bikker, O. W. Steenbeek, F. Torracchi. The Impact of Scale, Complexity, and Service Quality on the Administrative Costs of Pension Funds: A Cross-Country Comparison. Journal of Risk and Insurance 79, 477-514 (2012).

10. J. A. Bikker. Operating costs of pension funds: the impact of scale, governance, and plan design. Journal of Pension Economics and Finance 8, 63-89 (2009).

11. E. James. New Models for Old-Age Security: Experiments, Evidence, and Unanswered Question. The World Bank Research Observer 13, 271-301 (1998).

12. J. E. Stiglitz. An Agenda for Reforming Economic Theory. Frontiers of Economics in China, 14, 149-167 (2019).

13. M. Festić, J. Mencinger. The Perspective of Pension System Reformsin the New Meber States. PRAGUE ECONOMIC PAPERS 18, 291-308 (2009).

14. UN DESA. World Economics Situation and Prospects 2014: Country classification. [accessed https://www.un.org/en/development/desa/policy/wesp/wesp_current/2014Chap1_en.pd $\mathrm{f}$

15. B. E. Kritzer. Social security privatization in Latin America. Social Bulletin 63(2), 17 37 (2000). 